\title{
Unicompartmental Knee Arthroplasty
}

P. Cartier, J.A. Epinette, G. Deschamps, P. Hernigou (1997) Cahiers d'enseignement de la SOFCOT ( ${ }^{\circ} 61$ ), Expansion Scientifique Française, 305 p., US $\$ 150$ (ISBN 2-7046-1532-2)

This work, totally dedicated to the unicompartmental knee arthroplasty, is divided up into several parts dealing successively with biomechanics, imaging, surgical technique, the analysis of series and the indications.

The "biomechanics" part develops two important notions : the behavior of the prosthetized knee depending on whether the axial correction is an hypo-, a normo-, or an hyper-correction, as well as the study of the kinetics of the cruciate ligaments according to the thickness of the tibial plate, directly depending on the thickness of the tibial section. The study of the polyethylene accounts for the multifactorial problem of its behavior, and despite its evolution points to be the limiting factor. In the end, the analysis of the stresses accounts for the interest of the UHMWPE polyethylene, of the metal-back plate, of the reaxation with hypo-correcting and of the position of the prosthetic implants.

The imaging, very detailed, shows the interest of the under stress for the pre-operative planning. An amount of details is given in order to facilitate its understanding.

The operative technique is developed by different authors detailing key points, concerning the ways of approach, the osseous and the laxities.

At last the "indications" chapter appears synthetic, as it gives all the decisional factors. Some of them like the prosthetic anchorage, the integrity of the anterior cruciate ligament, the age and the weight may lead to a discussion. On the other hand, the place of the unicompartmental arthroplasty is therein well codified as compared to the osteotomy and the tricompartmental arthroplasty.

To conclude, this book is a good answer to its vocation of "teaching notebook", being exhaustive and didactical. Its reading will enable the orthopædician to get a precise idea of the interest of the unicompartmental knee arthroplasty, and to find the ways necessary to perform the ideal arthroplasty.

C. Boeri
Cet ouvrage, entièrement consacré à la prothèse unicompartimentale de genou, est divisé en plusieurs parties abordant successivement la biomécanique, l'imagerie, la technique chirurgicale, l'analyse des séries et les indications.

La partie "biomécanique" développe deux notions importantes : le comportement du genou prothésé selon que la correction axiale est une hypo-, une normo- ou une hyper-correction, ainsi que l'étude de la cinétique des ligaments croisés en fonction de l'épaisseur du plateau tibial, directement dépendante de l'épaisseur de coupe tibiale. L'étude du polyéthylène rend compte du problème multifactoriel de son comportement, et s'annonce malgré son évolution comme le facteur limitant. En final, l'analyse des stress rend compte de l'intérêt du polyéthylène UHMWPE, du plateau métal-back, de la réaxation avec hypo-correction et de la position des implants prothétiques.

L'imagerie, très détaillée, démontre l'intérêt des clichés en stress pour la planification préopératoire. Une somme de détails est donnée pour en faciliter la compréhension.

La technique opératoire est développée par différents auteurs en précisant les points clefs, quant aux voies d'abord, aux coupes osseuses et aux laxités.

Enfin le chapitre "indications" apparaît synthétique, puisqu'il donne tous les facteurs décisionnels. Certains comme l'ancrage prothétique, l'intégrité du ligament croisé antérieur, l',ge et le poids pourront prêter à discussion. Par contre, la place de la prothèse unicompartimentale y est bien codifiée par rapport à l’ostéotomie et la prothèse tricompartimentale.

En conclusion, ce livre répond bien à sa vocation de "cahier d'enseignement", en étant exhaustif et didactique. Sa lecture permettra à l'orthopédiste de se faire une idée précise de l'intérêt de la prothèse de genou unicompartimentale, et de trouver les moyens nécessaires à la réalisation de l'arthroplastie idéale.

C. Boeri

\section{Forefoot Surgery}

B. Valtin (1997) Cahiers d'enseignement de la SOFCOT ( $n^{\circ} 60$ ), Expansion Scientifique Française, 165 p., US\$ 110 (ISBN 2-7046-1531-4)

This work, the English version of study no. 6o, is entirely dedicated to forefoot surgery. It deals successively with anatomy and biomechanics, hallux valgus, the metatarsalgias, the pathologies of the small toes, Morton's and Freiberg's diseases, the rheumatoid foot, canalar syndromes and ortheses.

As anatomy and biomechanics are discussed to with aid understanding of the pathology, we must regret the absence of a chapter dedicated to imaging whose importance is not irrelevant to the orientation of therapeutic indications.

The "Hallux valgus" chapter describes in an exhaustive manner the different surgical approaches, but without thoroughly studying techniques such as distal, bipolar or diaphyseal metaphyseal osteotomies.

The "New osteotomies" chapter written by Barouk, details perfectly the Scarf and Weil osteotomies, very fashionable at the moment. Yet the author privileges, to my sense, too much the new ancillaries such as the Scarf screw, suture clips with memory or sectile suture clips, whose heavy cost can be limited by the use of standard screws or staples without detriment to the final result.

The "metatarsalgias" chapter seems to be succinct, though as a reminder on the taking and analysis of the plantar print would have been appreciated.

The "little toe pathology" and "Freiberg disease" chapters do not call for any criticism, as they give all the decisional and technical factors.

Lastly, the chapter dedicated to ortheses gives a very useful budget of informations within the therapeutic range.

In conclusion, despite some omissions, this book answers the reader's expectations by supplying current data and recent techniques.

C. Boeri 